Furthermore, in many cases permeation of tissue fluid has limited the survival of the system.

In Britain work on cochlear implants has been carried out by the External Pattern Input Group, funded by the Medical Research Council. The group has taken a different approach from that of the Americans and has made three important contributions. ${ }^{7-9}$ Firstly, it showed that an electrode placed outside the cochlea could provide a range of hearing similar to the intracochlear device while avoiding some of its potential complications. This led to the development of extracochlear prostheses, which have proved popular in many countries because of the widespread concern at the prospect of invading the cochlea, especially in children. ${ }^{1011}$ Secondly, the group showed that if the tympanic membrane is removed or stuck down into the inner wall of the middle ear the electrode system may be inserted and taken out in much the same way as a hearing aid mould. Some patients in Britain are already using an entirely external system successfully, though it has not proved widely popular; even so, it is so much cheaper than a permanently implanted device that it may prove to be the treatment of choice. The third, and probably the most important, contribution has yet to realise its full potential. It entails the extraction of appropriate patterns from the speech signal by a microcomputer before its transformation into simple electrical signals. Matching one stimulus pattern to a lower frequency has already proved advantageous and recent work suggests that some patterns may allow the perception of fricatives-the continuous consonants such as $f$ and $z$.

Throughout the world hundreds of patients have been given cochlear implants of one sort or another with varying improvement in their perception of sound. What they hear, however, is far from normal speech. They may recognise changes in tone well enough to distinguish questions from statement; they may learn to appreciate vowel sounds; they perceive the stress on each syllable and understand speech $c$ very much better than they would by lip reading alone. $\bar{T}$ Nevertheless, these devices do not give the subtlety of normal hearing mechanisms, and more work must be done to enhance our understanding of the hearing mechanism and to design more advanced prostheses. Meanwhile, the present $\stackrel{?}{.}$ range of implants offer a measure of hope for the totally deaf and have excited much interest among the public. Those who fit the new prostheses will, we hope, choose to publish their first results in the scientific journals rather than in the daily press.

Consultant Otologist

Ellis Douek

External Pattern Input Group,

Guy's Hospital,

London SE1 9RT

1 Diourno A, Ayries C. Prosthese auditive par excitation electrique a distance du nerf sensoriel à l'aide d'un bobinage inclus a demeure. Presse Médicale 1957;35:14-7.

2 Simmons FB. Electrical stimulation of the auditory nerve in man. Arch Otolaryngol 1966;84:24-76.

3 House WF, Urban J Long term results of electrode implantation and electronic stimulation of the cochlea in man. Ann Otol Rhinol Laryngol 1973;82:504-18. Michelson RP, Schindler RA. Surgical approach for insertion of multichannel electrodes into the
. scal

Chouard CH, Fugain C, Meyer B, Lacombe H. Résultats cliniques de l'implant cochleaire a houard CH, Fugain C, Meyer B, Lacombe H. Résultats cliniques de l'implant cochleair
multiélectrodes. Annales d'Otolanyngologie et de Chirurgie Cervico-faciale 1982;99:154-88. Clark GM, Tong YC, Dowell RC. Clinical results with a multichannel pseudobipolar system. Ann NY Acad Sci 1983;405:370-6.

7 Douek E, Fourcin AJ, Moore BCJ, Clarke GP. A new approach to the cochlear implant. Proceedings of the Royal Society of Medicine 1977;70:379-83.

8 Fourcin AJ, Douek E, Moore BCJ, et al. Speech perception with promontory stimulation. Ann 6 NY Acad Sci 1983;405:280-94.

9 Moroe BCJ, Douek E, Fourcin AJ, et al. Extracochlear cochlear stimulation with speech pattern: experience of EPI Group (UK). Advanced Audiology 1984;2:148-62.

10 Burian K, Eisenwort B, Hochmair ES, Hochmair-Desoyer I. Clinical experiences with the 'Vienna cochlear implant.' Advanced Audiology 1984;2:19-29.

1 Banfai P, Hortmann G, Karczag A, Kubik S, Wustrow F. Results with eight-channel cochlear implants. Advanced Audiology 1984;2:1-18.

\title{
Media drug campaigns may be worse than a waste of money
}

The government is rightly concerned about the proliferation of the misuse of drugs, but in its anxiety to be seen to be doing something about the problem it may be about to make a mistake. In London the Department of Health and Social Security has set aside $£ 2 \mathrm{~m}$ for a prevention campaign ${ }^{1}$ and will announce at the end of the month how exactly it will spend the money. In Edinburgh the Scottish Home and Health Department has already instructed the Scottish Health Education Group to mount a mass media campaign on drug misuse. To spend money in this way is to go against the advice of the government's experts that campaigns in the press and on television may be worse than useless: not only may they be a waste of much needed money but they may increase the prevalence of drug misuse.

Last year the Advisory Council on the Misuse of Drugs, which was set up more than 10 years ago to advise ministers, produced a report on preventing drug problems. ${ }^{2}$ On page 17 it reports the Health Education Council's advice that "caution should be exercised in the use of widespread publicity . . . partly because of the risk that ill chosen educational methods attach disproportionate importance to drug misuse and arouse in some people an interest which they would not otherwise have felt." After weighing all the evidence the advisory council bluntly stated: "National campaigns aimed specifically at reducing the incidence of drug misuse should not be attempted."”

This recommendation is supported by many other studies. Dr Nick Dorn, of the Institute for the Study of Drug
Dependence in London, writes in an important review that "no known methods of drug education can be said to reduce drug use." 3 Other large reviews from the United States have noted the ineffectiveness of most drug education campaigns while at the same time recognising the inadequacy of most studies of this matter. ${ }^{46}$ One review looked specifically at students and concluded: "Among student populations there is evidence to suggest that these programmes may exacerbate the use and sale of drugs." 4

What ministers in London and Edinburgh should realise $\mathrm{O}$ (and they have been told) is that unemployed youngsters on Merseyside do not react in the same way to exaggerated drug $\rightarrow$ campaigns in the media as do their middle aged constituents in Rushcliffe and Argyle and Bute. Ministers should listen to the advice of their experts; it would be a great shame if the N experts were left with the impression that ministers care $\sigma$ more about what their constituents think of the campaigns than about what effect the publicity may have on potential young drug takers.

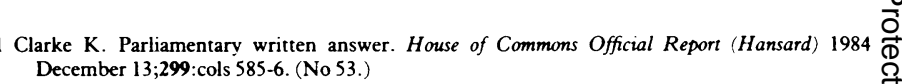

2 Home Office. Prevention: report of the Advisory Council on the Misuse of Drugs. London: HMSO, 1984.

3 Dorn N. Social analyses of drugs in health education and the media. In: Busch C, Edwards SG, eds. Drur arnh! me in Rritoin. I.ondon: Academic Press, 1981:281.

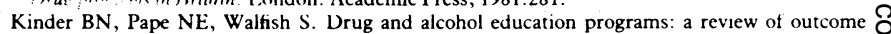
studies. Int $\mathcal{F}$ Addict 1980;15:1035-54.

5 Schaps E, DiBartolo R, Moskowitz J, Palley CS, Churgin S. A review of 127 drug abuse prevention program evaluations. Fournal of Drug I ssues 1981;11:17-43.

6 Bandy President PA. Recent literature on drug abuse prevention and youth, parents, women, and the elderly. Fournal of Drug Education 1983;13:255-71.
} 